\title{
In Silico Characterization of the Phytopathogenic Efector, avr3a, from Phytophthora cinnamomi
}

\author{
Iuliia Branco and Altino Choupina*
}

\author{
CIMO-Mountain Research Center, Agricultural College of Bragança, Polytechnic Institute of Bragança, \\ Bragança, Portugal
}

\begin{abstract}
Phytophthora cinnamomi is an Oomycete considered one of the most widespread and destructive pathogens on the planet. Its geographic presence is cosmopolitan and the range of hosts is regarded as one of the largest. This pathogen causes enormous economic damages to important cultures worldwide; this has helped to attract the attention of the scientific community. It is the causal agent of chestnut "ink" disease (Castanea sativa Miller).

The chestnut tree has different applications, besides chestnut and wood, it plays an important role in soil ecology and biodiversity. Therefore it is important to know the molecular mechanisms (genes and proteins) that are the basis of the Castanea sativa infestation process by Phytophthora cinnamomi and the nature of the pathogen-host interaction in order to establish strategies to combat and control this parasite.

With bioinformatics tools, we were able to identify and characterize the Avr3a gene in genomic sequences of $P$. cinnamomi deposited in the Databases. This gene encodes a recognized 209 aminoacids, protein in the host cytoplasm where it triggers cell death.
\end{abstract}

Keywords: Chestnut, Phytophthora cinnamomi, ink disease, Avr3a gene.

\section{INTRODUCTION}

Castanea sativa, commonly known as European chestnut, belongs to the genus Castanea of the Fagaceae family. It is distributed in 25 European countries, occupying about two million hectares. This species has special incidence in Spain, France, Greece, Italy, Portugal and Turkey. In Italy, the area planted with chestnut is the largest in Europe [1].

In Europe, during the 20th century, the production of chestnut decreased considerably, with losses of around 300 million euros; in North America, at the same time, the settlements of $C$. dentata almost disappeared. This decrease in production is mainly due to infections caused by pathogens that are lethal to the plant.

Chestnut ink disease, caused by Oomycetes Phytophthora cinnamomi (most virulent species) and Phytophthora cambivora, and chestnut cancer, caused by the fungus Cryphonectria parasitica, are the main and most serious diseases of the chestnut tree $[2,3]$. The ink disease of the European chestnut tree (Castanea sativa Miller) arose in Spain in 1726. In 1859 the symptoms of the disease were found in chestnut trees in northern Italy, in the provinces of Tuscany, Piedmont and Liguria; in France, in the regions of Gard, Lozère and the Low Pyrenees [4,5]. In Portugal, the first symptoms of the ink disease were

*Address correspondence to this author at the CIMO-Mountain Research Center, Agricultural College of Bragança, Polytechnic Institute of Bragança, Bragança, Portugal; Tel: (+351) 273303 200; Fax: (+351) 273303 372;

E-mail: albracho@ip recorded around 1838 on the banks of the Lima River, yellowing and premature falling of the leaves and the appearance of a wet rot in the roots which later led to the death of the tree [6]. Usually known as ink disease, since violet or dark blue exudates occur in the infected areas of the plant. When symptoms appear in the crown of the tree it may mean that the infection is very advanced, becoming difficult to eradicate $[1,7]$.

According to Gouveia, citing other authors, the effect of ink disease is considered by many to be the main cause of the decline and degradation of the soutos, the ink disease currently reaches epidemic proportions in Portugal $[8,9]$.

The pathogen Phytophthora cinnamomi is responsible for the ink disease affecting Castanea sativa in the Northeastern Transmontano region of northeast Portugal [10]. The Ink Disease invariably leads to the decline and death of the chestnut tree and the parasites once introduced into the soil, rapidly multiply and spread to ever wider areas. The production of propagating material of chestnut free of propagules of these parasites and the planting in soils where the parasites are not present are thus basic requirements for the success of the new chestnut plantations. In order to guarantee the quality of the propagation material and to know the health status of the soils, sensitive and rapid detection methods are necessary [11]. However, the great survival capacity of $P$. cinnamomi greatly complicates strategies to combat this Oomiceta [12]. 
In order to carry out an efficient control of a pathogen at the lowest cost, it is necessary to investigate all the available options. It is necessary to know the agent and when the agent is in the most susceptible phase of its life cycle. level of the pathogen; In this way, it will be necessary to know the host and what makes it more susceptible to the aggressor, acting at the host level (C. sativa); and, finally, how the environment influences both the pathogen and the host, controlling the environmental conditions that cause the disease. The pathogen, host and environment are the three most important elements on which control methods should be based. When measures that affect their interaction are applied, the disease is effectively controlled [13]

The genus Phytophthora belongs to the Chromista kingdom, Oomycota phylum, Oomycetes class, Pythiales order, family Pythiaceae [14].

It was traditionally classified in the Fungi kingdom, because they are organisms: heterotrophic, growth by polarization of the hyphae, vegetative spores adapted to the dispersion by the wind or the water and to use strategies of infection of the plants similar to the fungi. However, in Phytophthora, biological and physiological characteristics have always been recognized which gave it uniqueness in the context of the realm where it was inserted, and which were successively amplified with later studies [15].

As noted earlier, unlike other "true" fungi, most of their life cycle is diploid, cell walls are composed of cellulose and $\beta$-glucans instead of chitin, produce biflagellated zoospores and do not synthesize sterols, so are resistant to poly- genic antibiotics, such as pimaricin, but require sterols to sporulate [13].

These fungal-like eukaryotes, taxonomically classified as Oomycetes, generate asexual and sexed spores, with characteristics that greatly contribute to their pathogenic success [16].

Phytophthora belongs to a transition group between entirely aquatic and completely terrestrial fungi, reflecting on the complexity of its life cycle. This organism is dependent on moisture conditions for its survival, but has the ability to sporulate, disperse, infect and is able to adopt various strategies of adaptation to edaphoclimatic changes [17]. Several species of Phytophthora pose a threat to natural ecosystems, horticultural, tropical and subtropical, ornamental and forestry crops, and can cause serious economic losses.
Most species of Phytophthora are soil pseudo fungi that cause the destruction of the root system and can survive long periods in the soil without the presence of the host [13].

The taxonomic classification of the genus Phytophthora is based essentially on morphological characteristics. They present high plasticity and are small in number compared to the high number of species described, making classification and identification difficult, laborious and very time consuming [15].

The various species of the genus Phytophthora can infect all or only a few specific organs of host plants. Among the various manifestations of diseases can be mentioned: root rot, neck, fruit, foliar lesions, gomoses, wilt of the aerial part of the plant among others [18]

Plant pathogens use a variety of strategies to colonize and infect their hosts. After attacking and introducing themselves to the surface of the host, the necrotrophic pathogens grow through plant tissues as hyphae, while secreting a variety of enzymes and toxins that kill and degrade host tissues; Biotrophic pathogens, on the other hand, depend on living host tissues for nutrient uptake. Typically, biotrophic pathogens penetrate the host cell wall, but not the plasma membrane, by developing specialized feeding structures. Many pathogenic Oomycetes can be characterized as hemibiotrophic, since in an initial biotrophic phase it is eventually followed by a necrotrophic phase [19].

In order to establish a successful infection, pathogens need to modulate biochemical, physiological and morphological processes in their hosts. Oomycetes, usually through the secretion of proteins and other molecules collectively known as effectors [20].

Efectants are defined as all pathogenic proteins and small molecules that manipulate the structure and function of the host cell either by facilitating infection or by activating a defense response [21]. Many effector genes have distinct expression patterns during colonization of host plants [22].

Phytophthora cinnamomi was first described by Rands in 1922, after being detected in the cinnamon tree (Cinnamomi burmamii Blume) in Sumatra. It is an oomycete of the soil that essentially infers the roots of the host plants. This phytopathogen originating in the Papua New Guinea region now has a global 
distribution [23]. It is currently the most widely distributed Phytophthora species and the most destructive pathogen with a wide range of hosts, causing disease in approximately 1000 plant species [13].

This species, like other Oomycetes, has characteristics that allow it to be distinguished from many other pathogenic fungi. It is characterized in biological terms by having cenocytic mycelium, the hyphae are hyaline and may have a smooth knotty appearance and lateral branches usually present a slight constriction at the base [15].

In the Iberian Peninsula $P$. cinnamomi is a Oomycete associated with mortality of chestnut trees. Recent discoveries reveal the existence of an extensive class of Oomycetes that on the one hand contribute to plant infection and, on the other hand, trigger the plant's defense systems [23]. These findings provide an excellent aid to further studies to understand how these organisms trigger the recognition of defense cascades, which mechanisms are most resistant to the pathogen, and how it overcomes or suppresses these defenses [24,25].

These Oomycetes species can manipulate biochemical and physiological processes in host plants through a diverse set of molecules called effectors. In susceptible plants, these effectors promote infection by suppressing the defense mechanisms, reinforcing the susceptibility or causing symptoms of the disease [26].

In Oomicetas as in the case of Phytophthora cinnamomi the process of germination, sporulation, cell growth and pathogenicity has been related to altered cell wall structure [23].

Phytophthora cinnamomi is a mostly heterotálica species, producing the structures sexuadas from forms or mating types of type of opposite pairing. Usually the complementary forms are called $\mathrm{A} 1$ and $\mathrm{A} 2$. The $\mathrm{A} 2$ form of $P$. cinnamomi is the most common form and is distributed worldwide. The form $\mathrm{A} 1$ has a more restricted distribution. Oospores are structures of resistance, allowing the Oomycetes to survive outside the host for long periods of time. The main unit of the asexual phase of Phytophthora cinnamomi is the cenocytic hypha, which by cleavage of its cytoplasm gives rise to chlamydospores and sporangia [23].

Sporangia are the major asexual reproductive structures. They have the ability to germinate directly as mycelium or emit mobile zoospores [28].The zoospores are biflagellate, with two different flagella ones, that leave the concave part; are produced within the sporangium and are already formed. Other sexually reproducing asexual structures that are most frequently observed in liquid media are chlamydospores. They are the most frequent and persistent resistance structures in the soil [13].

$P$. cinnamomi is a soil pathogen that depends on favorable moisture conditions for its survival, sporulation and dispersion [17]. If the environmental conditions are adequate, especially the appropriate temperature and the existence of free water in the soil, these structures germinate, producing sporangia that release zoospores. Zoospores are considered the most important infection propagules because they can produce several generations during the period when environmental conditions remain appropriate $[13,27]$.

In addition to zoospores containing information about the chemical environment, they can also integrate information about the electrical environment, which seems to allow zoospores to distinguish the living roots from the dead and to contribute to the selection of the site of infection on the root surface [29]. When conditions are not favorable the fungus survives in the soil or tissues infected as chlamydospores that remain in the state of latency for more or less long periods. When stimulated by the presence of a host and favorable environmental conditions, the chlamydospores germinate giving rise to new infectious hyphae [30].

P. cinnamomi can survive on dead plant material, the saprophytic phase may lead to an increase in the population of the pathogen, although Phytophthora species have a limited saprophyte capacity which means that they present poor growth and of low competitive capacity to the presence of other microorganisms of the soil and plant [31]. Phytophthora cinnamomi is, as already mentioned, one of the most destructive known pathogens, causing massive death of absorbent roots, which reduces the plant's ability to absorb water and nutrients [27]. When overcoming all barriers the pathogen is installed in the host and the most evident external symptoms appear in the upper part of the crown progressing from top to bottom, from the end of the branches [33].

The main objective of this work is to contribute to the understanding of the molecular mechanisms that underlie the infectious process of Castanea sativa by Phytophthora cinnamomi and thus to understand the 
nature of the pathogen-host interaction. This may represent an important contribution to the establishment of control strategies for diseases caused by Phytophthora species to important crops such as chestnut. To achieve this general objective, we have established the following specific objectives: Search of genes in the genomic sequences of Oomiceta Phytophthora cinnamomi, deposited in Databases; Identification, by homology, of molecular factors (genes/proteins) implicated in the pathogenicity of Phytophthora cinnamomi; Bioinformatic characterization and subcellular localization of identified molecular factors.

\section{METHODOLOGIES}

\section{Sequence Editing and Comparison}

For the detailed edition of the sequences was used BioEdit program, whose version is available at http://www.mbio.ncsu.edu/bioedit/page2.html. For sequence comparison and annealing, we used the Sequencher program from Gene Codes Corporation, whose demo copy of version 5.2.4 is available at www.genecodes.com.

\section{Biological Information Databases}

For the research of genes we used the sequences of the genome and the transcriptome of Phytophthora cinnamomi, deposited in the databases:

NCBI (National Center for Biotechnology Information) at https://www.ncbi.nlm.nih.gov/;

EMBL (European Molecular Biology Laboratory) at www.ebi.ac.uk/ena;

DDJB (DNA Data Bank of Japan) at www.ddbj.nig.ac.jp/;

FungiDB (The Fungal and Oomycete Genomics Resource) at fungidb.org.

\section{Open Reading Frame Search}

For the search of open reading frames, in the sequences of the genome and the transcriptome of $P$. cinnamomi, the following programs were used:

ORF finder da NCBI at https://www.ncbi.nlm.nih.gov/ orffinder/;

GGENEinfinity at http://www.geneinfinity.org/sms/sms_ orffinder.html;
GGenScript at https://www.genscript.com/sms2/orf find.html.

\section{Homology of Proteins Encoded by Open Reading Frames}

Detection of protein homology and sequence alignment underlies the prediction of protein structure, function, and evolution. Protein homologies were determined in the Blast (smartBlast), Clustal Omega and Fasta programs independently or through NCBI (National Center for Biotechnology Information). Its use is simple by simply needing to paste the studied sequence into the program window and ask the program to establish homology with the Protein Databases sequences: UniProt Universal Resource (EBI), Protein Information Resource (PIR, Georgetown University Medical Center (GUMC)), Swiss-Prot Protein Knowledgebase (Swiss Institute of Bioinformatics) and PROSITE (Database of Protein Famines and Domains).

\section{Prediction of Subcellular Localization of Proteins}

The prediction of the subcellular localization of proteins predicts the fate of a protein in the cell by means of computational methods that from the sequence of proteins produce a prediction of the location of the protein.

There are several publicly available software, using different methods to predict protein localization (amino acid composition, signal peptide composition, physicochemical composition, among others), which is a very important part of the prediction based on protein function bioinformatics and genome annotation.

The software used for prediction of protein localization can be accessed through the URL addresses as follows:

SignalP 3.0: http://www.cbs.dtu.dk/services/SignalP3.0/;

Cello: http://cello.life.nctu.edu.tw/;

LOCtree: https://rostlab.org/services/loctree2/;

EuK-mPLoc 2.0: http://www.csbio.sjtu.edu.cn/bioinf/ euk-multi-2/;

Esl pred: http://www.imtech.res.in/raghava/es/pred/ index.html. 


\section{Bioinformatics Characterization of Molecular Factors}

After decoding the open reading frame of a gene, a number of bioinformatic tools can be used to characterize the deduced sequence of the protein. A search on the Expasy Proteomics Server website (http://expasy.org/tools) and a nucleotide sequence allow us to identify and characterize proteins, identify motifs, patterns and profiles, infer their stability, cell location or function, predictions of secondary and tertiary structures, look for similar sequences deposited in databases and compare them, establish phylogenetic relationships.

The detection of the physical-chemical characteristics of the proteins was carried out in PROSITE (http://prosite.expasy.org/scanprosite/), in the neural network system of the Pôle Biolnformatique Lionnais / Network Protein Sequence Analysis or in the application DiANNA $1.1 \quad$ (http://clavius.bc.edu/ $\sim$ clotelab/DiANNA/). Different sites were predicted for post-translational modifications on the Center of Biological Sequence Analysis website (http://www.cbs.dtu.dk/services). The structural predictions were made through the server Phyre2 (http://www.sbg.bio.ic.ac.uk/phyre2/html/) and the structural representation made through the Pymol program, whose version can be installed in https://www.pymol.org/.

Although Internet URL addresses can be preserved for some time, they are likely to change locations for a variety of reasons. Therefore, we recommend upgrading by going directly to the old address or through some search engine such as "Google" (https://www.google.com), typing the most appropriate keyword(s).

\section{PRESENTATION AND DISCUSSION OF RESULTS}

\section{Genes Associated with Pathogenicity in Phytophthora cinnamomi}

With the objective of knowing the molecular factors (genes and proteins) associated to the pathogenicity mechanisms of Phytophthora cinnamomi identified and characterized until this moment, we started by searching the references and databases already mentioned in the methodologies (NCBI, EMBL, DDJB and FungiDB) nucleotide and protein sequences as well as publications on the subject. To our surprise, since it is a very important phytopathogenic agent on a global scale as was emphasized in the introduction of this work, and the number of molecular factors linked to the pathogenicity of $P$. cinnamomi studied to date is very small, as can be (Table 1) and did not cover a simple metabolic pathway despite the large amount of sequencing data from the genome of this fungus resulting from modern and massive sequencing platforms.

The molecular factors associated with the pathogenicity of $P$. cinnamomi, more studied up to the present moment, are: NPP1 ( $P$. cinnamomi necrosis inducing protein 1), responsible for inducing necrosis in leaves and roots of plants, leading to their death; GIP (glucanase inhibitor protein) responsible for suppression of the host defense response; GLUCANASES responsible for adhesion, penetration and colonization in host tissues and POLIGALACTURONASES, which hydrolyze the alpha1,4 glycosidic bonds between the galacturonic acid residues.The polygalacturonane, whose main component is galacturonic acid, a very important carbohydrate compound of the pectin network that enters the cell wall composition of the plant cells [34, 35].

\section{Phytophthora cinnamomi Coding Sequences with Importance in Pathogenicity}

Of the coding genomic sequences of $P$. cinnamomi deposited in the Databases are the polygalacturonases. Götesson et. al., in 2002, carried out an important study on polygalacturonases (PGs) of $P$. cinnamomi. A fragment of the $P$. cinnamomi polygalacturonase gene was amplified using degenerate primers based on conserved regions in fungal and plant PGs, this fragment was then used as a probe to isolate 17 complete $P$. cinnamomi genes and pseudogenes from one genomic library, as well as the partial sequence for two other genes. Southern blotting of genomic DNA indicated that there may be even more $P G$ genes in the $P$. cinnamomi genome. Sequences of $P$. cinnamomi $P G$ genes were expressed in $P G$ deficient yeast where they confer PG activity, thus confirming their functional identity. According to these authors, the predicted $P$. cinnamomi $\mathrm{PGs}$ fall into subgroups that exhibit large differences in the extent of $\mathrm{N}$-glycosylation, isoelectric points, and $\mathrm{N}$ and $\mathrm{C}$ terminal structure. Evidence of birth and death, and reticulated evolution in the $\mathrm{pg}$ gene family of $P$. cinnamomi were obtained. Contrary to accepted phylogenies for other proteins, phylogenetic analysis of $P$. cinnamomi $\mathrm{PGs}$ revealed a closer relationship with true fungal PGs than with plant fungi [34]. 
Table 1: Genes Linked to Pathogenicity in Phytophthora cinnamomi

\begin{tabular}{|c|c|c|c|}
\hline Gene name & Source & Protein Name & Function \\
\hline endo1 & $\begin{array}{c}\text { NCBI } \\
\text { Accession: AM259651 }\end{array}$ & $\begin{array}{l}\text { glucan } 1,3 \text {-beta-D- } \\
\text { glucosidase }\end{array}$ & $\begin{array}{l}\text { Morphogenetic processes of the cell, especially } \\
\text { in the process of infection. }\end{array}$ \\
\hline gip & $\begin{array}{c}\text { NCBI } \\
\text { Accession: AM259384 }\end{array}$ & glucanase inhibitor protein & $\begin{array}{l}\text { Responsible for suppressing the host defense } \\
\text { response. }\end{array}$ \\
\hline npp1 & $\begin{array}{c}\text { NCBI } \\
\text { Accession: AM403130 }\end{array}$ & protein 1 & $\begin{array}{l}\text { It causes necrosis in the leaves and roots of the } \\
\text { plant. }\end{array}$ \\
\hline Transglu & $\begin{array}{c}\text { NCBI } \\
\text { Accession: AM403129 }\end{array}$ & $\begin{array}{l}\text { transglutaminase elicitor } \\
\text { precursor }\end{array}$ & $\begin{array}{l}\text { It induces defense responses and symptoms } \\
\text { similar to that of the disease. }\end{array}$ \\
\hline endoglucanase & $\begin{array}{l}\text { Appl Microbiol Biotechnol 98: } \\
\text { 3905-3909. Springer. }\end{array}$ & endo-1,3-beta-glucanase & Responsible for mechanisms of infection. \\
\hline exoglucanase & $\begin{array}{l}\text { Appl Microbiol Biotechnol 98: } \\
\text { 3905-3909. Springer. }\end{array}$ & exo-glucanase & $\begin{array}{l}\text { Responsible for adhesion, penetration and } \\
\text { colonization in host tissues. }\end{array}$ \\
\hline $\begin{array}{l}\text { ADP-ribosylation } \\
\text { factor }\end{array}$ & $\begin{array}{l}\text { Mol Genet Genomics. } 2010 \text { Dec; } \\
284 \text { (6): 425-435 }\end{array}$ & ADP-ribosylation factor & Responsible for mechanisms of infection. \\
\hline Ric1 protein mRNA & $\begin{array}{l}\text { Mol Genet Genomics. } 2010 \text { Dec; } \\
284 \text { (6): 425-435 }\end{array}$ & Ric1 protein mRNA & Responsible for mechanisms of infection. \\
\hline $\begin{array}{c}\text { polygalacturonase } 4 \\
1,2,3 \text { e } 4,5,6\end{array}$ & $\begin{array}{l}\text { Mol Plant Microbe Interact. } 2002 \\
\text { Sep; } 15 \text { (9): 907-21 }\end{array}$ & polygalacturonase 4 & Ruture in cell wall composition of plant cells. \\
\hline highly acidic elicitin & DNA Seq. 1998; 9 (4): 231-237 & highly acidic elicitin & Responsible for mechanisms of infection. \\
\hline
\end{tabular}

\section{Genomic Sequences of Phytophthora cinnamomi}

In the European biological databases http://www.ebi.ac.uk/ena, there is also a deposited transcript consisting of 37575 sets of Phytophthora cinnamomi sequences [36]. In addition to these sequences, there are also 39509 sets of sequences with deduced function in the NCBI, 5 EST (Expressed Sequence Tags), and 1 GSS (Genome Survey Sequences). These sequences code mostly for different subunits of ribosomal, mitochondrial RNA, and genes of the fundamental metabolism of $P$. cinnamomi. Of the 1289 proteins deposited, most are partial and have structural (tubulin and actin) and functional functions of different metabolic pathways (synthetases, oxidases, and kinases), in addition to several mitochondrial proteins.

The study of genomic sequences, their products, their functions and interactions, will allow elucidating the genetic and molecular mechanisms, defense and attack strategies of the $P$. cinnamomi Oomycete, in order to establish more efficient and resilient control strategies.

The bioinformatics analysis of the deposited sequences of the Phytophthora cinnamomi genome carried out in the program "Open Reading Frame Finder-ORFfinder - NCBI", and in other research programs of open reading phases mentioned in the methodologies of this work, allowed us to find phases of open reading that encode proteins with different "domains" and high homology with proteins with a relevant role in virulence in different species of the genus Phytophthora.

Figures 1 and 2 represent the putative open reading frames of the sequences with the references LGSJ01000006.1, with 63 reading phases and LGSK01000001.1 with 64 reading phases, respectively, obtained from the $\mathrm{NCBI}$ ORF-finder program and deducted from clusters equal to or greater than 300 nucleotides, considering ATG as the start codon and TGA, TAG and TAA as STOP or stop codons, the universal genetic code and including internal open reading frames.

Using the homology programs, especially SmartBLAST, we made a comparison of the proteins deduced from the obtained open reading phases, in order to find homologous proteins characterized in other living beings and deposited in the UniprotKB and Swiss-Prot protein databases. In both sequences, most of the open reading phases encode proteins homologous to metabolism proteins of different species of the genus Phytophthora, as expected, especially $P$. infestans, $P$. sojae, $P$. nicotianea and $P$. parasitica. There are also a large number of open reading frames 


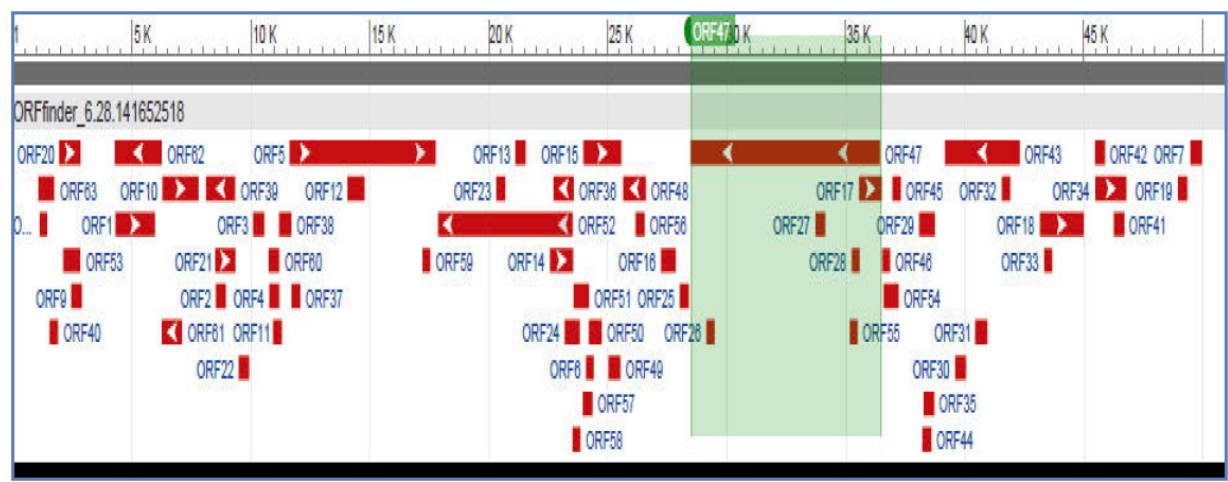

Figure 1: Open reading frames deduced from the sequence LGSJ01000006.1 of $P$. cinnamomi deposited in the NCBI database. The direction of the arrows indicates the reading direction of the open reading phases with significant size in the sequence.

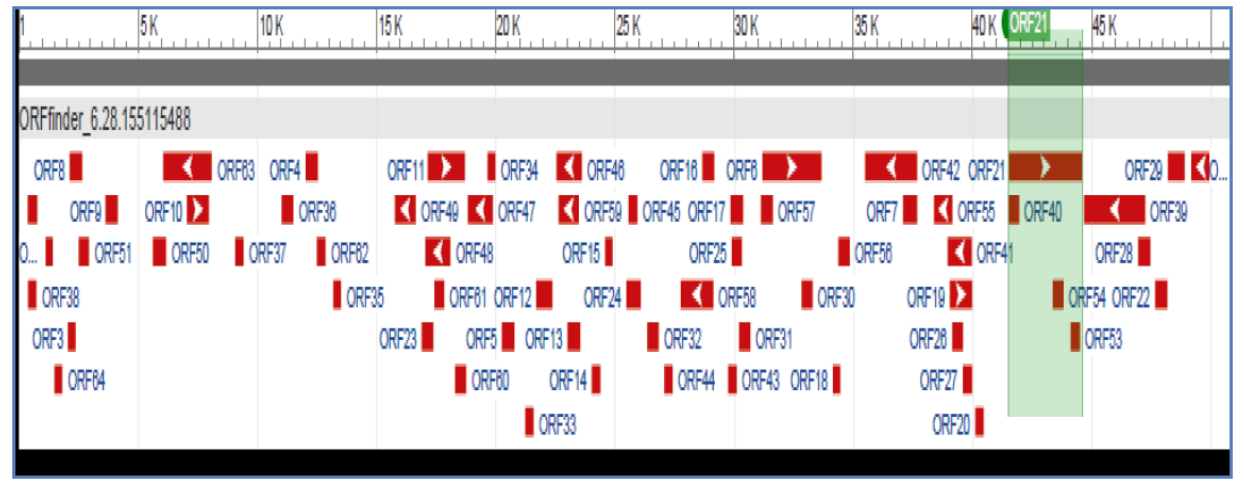

Figure 2: Open reading frames deduced from the sequence LGSK01000001.1 of $P$. cinnamomi deposited in the NCBI database. The direction of the arrows indicates the reading direction of the open reading frames with significant size in the sequence.

that code for hypothetical proteins and/or with no known function.

\section{Characterization of the Avr3a Factor, Associated with the Pathogenicity of $P$. cinnamomi}

Of the open reading frames deduced in the NCBI ORF Finder program from the sequence LGSK01000001.1, the reading phase number 49 (Figure 3) located on the complementary reverse tape of this sequence in "Frame" 3 , with a size of $873 \mathrm{nt}$ (position 16645-15773 of the sequence), codes for a putative protein with 290 amino acids and with significant homology with the Avr3a proteins of species of the genus Phytophthora namely Phytophthora megakarya (66\%), Phytophthora sojae (88, 84 and $82 \%$ ) and Phytophthora infestans ( $67 \%$ ) according to the smartBlast and Clustal Omega programs.

Armstrong et al. in 2005, used association genetics to identify Avr3a in $P$. infestans and showed that it encodes a protein that is recognized in the host's cytoplasm (Solanum demissum), where it triggers cell death [37].
Bos et al. in 2010 silenced the Avr3a gene in $P$. infestans by interference RNA and subsequently infected Nicotiana benthamiana with strains obtained from silencing and with wild $P$. infestans having concluded with these assays that Avr3a is an essential factor in the virulence of $P$. infestans, capable of manipulating the immunity of infected plants [38].

The study of the function of this open reading frame (ORF49) by silencing with interference RNA and subsequent infection of $C$. sativa with wild $P$. cinnamomi and with the silenced strains will be very important because it is a possible virulence factor of $P$. cinnamomi, given the significant similarity with the Avr3a proteins described, as can be seen in the phylogenetic tree in Figure 4.

\section{Subcellular Location of the Avr3a Factor of $P$. cinnamomi}

Determining the location of proteins involved in the fungal infection processes allows us to know how the parasite invades the plant, being important to 


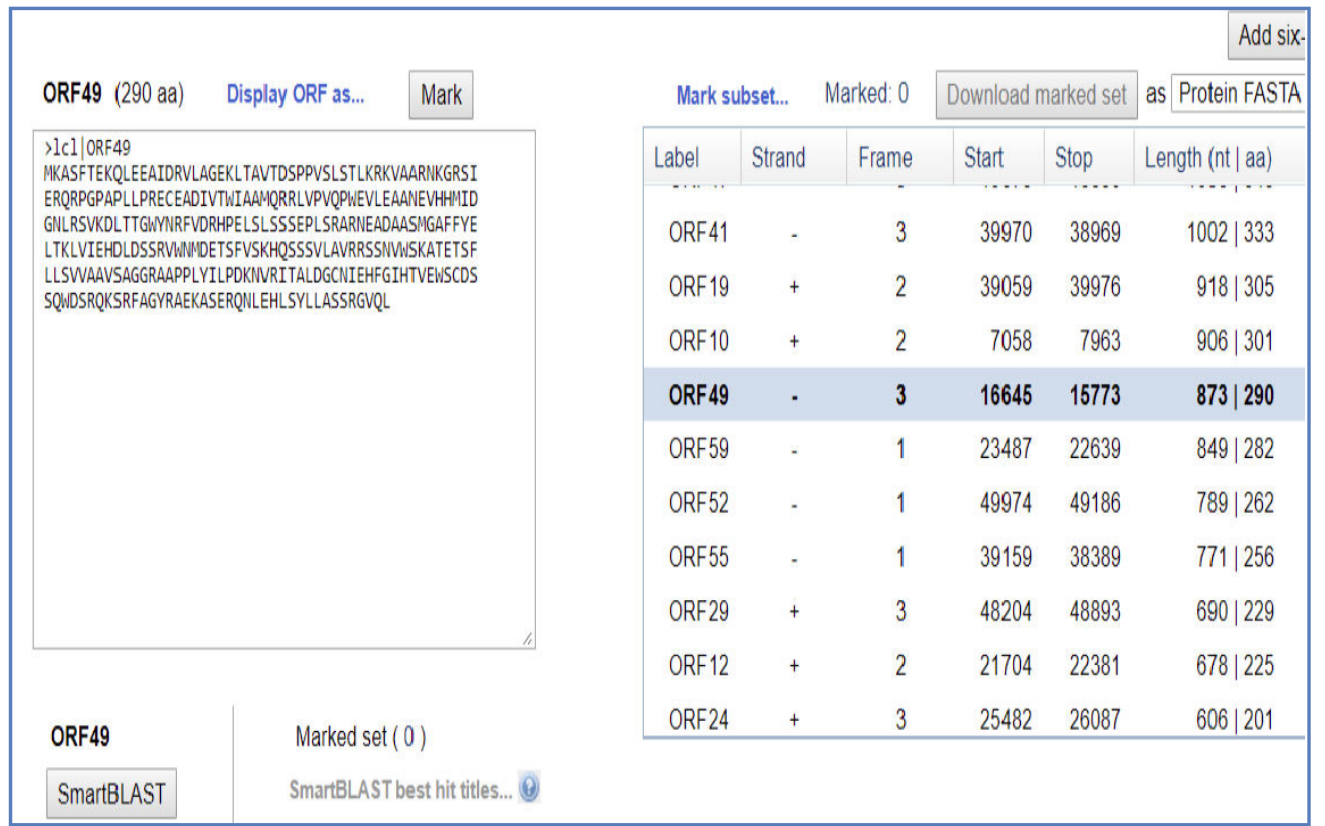

Figure 3: ORF49 that encodes the Avr3a protein with 290 amino acids, whose sequence is represented on the left part of the figure according to ORF Finder - NCBI.

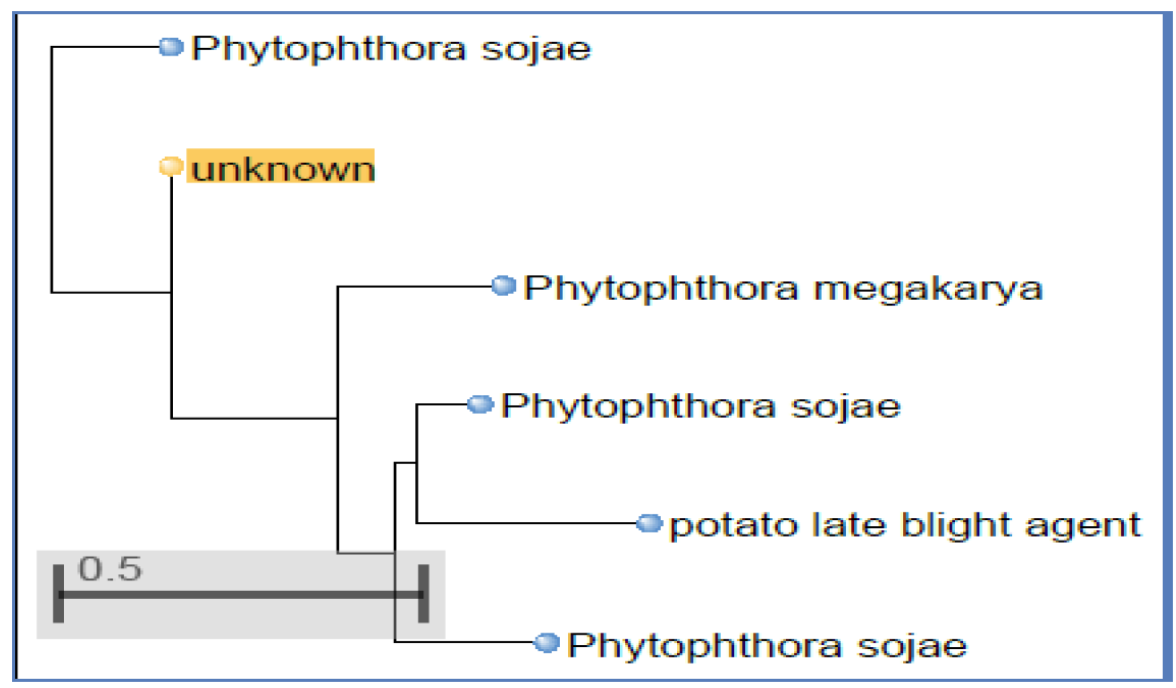

Figure 4: Phylogenetic tree of Avr3a proteins from Phytophthora cinnamomi (unknown in the figure) with different species of the Phytophthora genus.

understand the functions of proteins and consequently can facilitate the treatment of diseases.

Various software described in 3.5. are publicly available and have been used to predict the location of the proteins we characterize.

For the prediction of the AVR3a protein, many software was used with different prediction methods (Amino Acid Composition, N-peptide Composition, Physical-chemical Composition, among others), indicating most of them the nuclear destiny for this protein.
According to the SignalP 3.0 program, this protein does not have the signal peptide. The signal peptide is a small sequence of amino acids present at the $\mathrm{N}$ terminal end of proteins that ensure its transport to the ER (endoplasmic reticulum) for subsequent transport through the secretion pathway: Endoplasmic reticulum - Golgi complex - secretion vesicles and cell [39]. However, this fate is not consistent with the function of this protein, because, in order to be recognized in the cytoplasm of the host where it triggers cell death, it must be excreted. 
The prediction we make for homologous proteins including that of $P$. infestans, tells us that the location of these proteins is diverse from mitochondrial, extracellular, and cytoplasmic. These proteins are possibly secreted, but not through the classical ERGolgi pathway (via signal peptide), but through unconventional protein secretion processes. Therefore, it would be important to experimentally study the secretion pathway of this protein through its fusion with the green fluorescent protein (GFP) and subsequent homologous and/or heterologous expression with fluorescence microscopy observations of transformants' cells during growth.

Recent DNA sequencing techniques with platforms that allow massive sequencing combined with advanced bioinformatics capabilities, allow us to deduce the role of many molecular factors in the metabolic pathways. It is possible that many molecules have roles in metabolic pathways unknown to date.

\section{CONCLUSIONS}

The word Phytophthora is derived from the ancient Greek language and means plant destroyer. It is urgent, if not to eliminate, at least halt the harmful action of these microorganisms, whose action is already being felt worldwide by the rapid dissemination of these pathogens enhanced by climate change. If we do not do so, we risk terrible consequences, not only for the environment, by the destruction of natural flora, but also in terms of the human way of life, as happened in the 19th century, in the sad episode of the Great Famine verified in Ireland, caused by the destruction of potato crops by $P$. infestans [40].

The identification of the molecular factors associated with the infection mechanism of Castanea sativa by Phytophthora cinnamomi and the nature of the pathogen-host interaction mediated by interference RNA is very important as it creates a starting point for the development of strategies to control diseases caused by species Phytophthora spp. to important cultures.

With the identification of the molecular mechanisms of infection of Phytophthora-host, we will be able, for example, to silence the Phytophthora genes involved in the infection by generating interference RNA in the host [41]. This constituted, from the biotechnological point of view, a new tool for resistance strategies of host plants of Phytophthora spp., as well as other plant parasites.
In this context and from our work, we can present the following conclusions:

Although in the Databases two sequences of the genome of $P$. cinnamomi and one sequence of the transcriptome are found, they are poorly organized and have little information deduced;

The number of molecular factors linked to the pathogenicity of $P$. cinnamomi, studied until now, is very small, with glucanases and polygalacturonases standing out as the most studied factors.

In the genome of $P$. cinnamomi, we identified a sequence with a size of $873 \mathrm{nt}$ that codes for a protein with 290 amino acids and with significant homology with Avr3a proteins associated with pathogenicity in different species of the Phytophthora genus;

Although Avr3a proteins are identified in the cytoplasm of host cells where they trigger cell death, they do not have a signal peptide or a clear secretion pathway.

\section{CONFLICTS OF INTEREST}

The authors declare that there are no conflicts of interest. Also, are indebted to the careful and constructive criticisms of the reviewers.

\section{REFERENCES}

[1] Gomes-Laranjo J, Peixoto F, Ferreira-Cardoso J. Castanheiros, Técnicas e Práticas $1^{\text {a }}$ ed.; Pulido Consulting - Industria Criativa \& Universidade de Trás-os-Montes e Alto Douro 2009.

[2] Silva J. Árvores e Florestas de Portugal: Do castanheiro ao teixo. As outras espécies florestais; Lisboa: Publico, Comunicação Social, S.A. 2007; Vol. 5.

[3] Costa $\mathrm{R}$, Bragança $\mathrm{H}$, Machado $\mathrm{H}$. Os últimos 75 anos de investigação param o melhoramento do castanheiro em Portugal. Agrorrural - Contributos Científicos 2011; 915-926

[4] Crandall S. The distribution and significance of the chestnut root rot Phytophthoras, $P$. cinnamomi and $P$. cambivora. Plant Dis Rep 1950; 34(6): 194-196.

[5] Elorrieta J. El castaño en España. IFIE. Madrid, p333. Cit. by Gomes-Laranjo J, Peixoto F, Ferreira-Cardoso J. Castanheiros, Técnicas e Práticas. $1^{\text {a }}$ ed. (1949); Pulido Consulting - Industria Criativa \& Universidade de Trás-osMontes e Alto Douro 2009.

[6] Fernandes C. A luta contra a "doença da tinta" dos castanheiros no Norte de Portugal. Separata das publicações da Direção Geral dos Serviços Florestais e Aquícolas 1953; Vol. XX: Tomo: 153-158.

[7] Serrazina S. Isolamento e caracterização de genes de resistência à doença da tinta em Castanea sativa Mill. Universidade de Lisboa, Faculdade de Ciências 2004; Doctoral tesis.

[8] Gouveia M. Doença da Tinta do Castanheiro. Avaliação da resistência à Phytophthora cinnamomi Rands. Universidade 
Técnica de Lisboa - Instituto Superior de Agronomia, Lisboa 1993; Master tesis.

[9] Abreu C, Carvalho L, Gaspar M, Gomes A, Colaço J, Cardoso A. Assessment of resistance to chestnut ink disease. Acta Horticulturae 1999; 494: 363-367. https://doi.org/10.17660/ActaHortic.1999.494.55

[10] Choupina A, Dominguez A, López M, Martins I. Isolation and Sequencing of Actin1, Actin2 and Tubulin1 Genes Involved in Cytoskeleton Formation in Phytophthora cinnamomi. Plant Pathology \& Microbiology 2013; 4: 8.

[11] Gouveia M. Um método eficiente para a detecção de Phytophthora cinnamomi associada com a Doença da Tinta do Castanheiro na rizosfera de Castanheiro (Castanea sativa Mill.). Revista de Ciencias Agrárias 2009; 32(1): 130-138.

[12] Hwang S, Ko W. Biology of Chlamydospores, Sporangia, and Zoospores of Phytophthora cinnamomi in Soil. Phytopathology 1978; 68: 726-731. https://doi.org/10.1094/Phyto-68-726

[13] Erwin D, Ribeiro O. Phytophthora diseases worldwide. St. Paul, Minnesota, USA: APS Press 1996.

[14] Hawksworth D, Kirk P, Sutton B, Pegler D, Ainsworth \& Bisby's. Dictionary of the Fungi. Wallingford: Oxon CAB International 1995; 8th Ed., ISBN: 0851988857.

[15] Gouveia M. Métodos moleculares na identificação, caracterização e detecção de Phytophthora cambivora (Petri) Buisman e Phytophthora cinnamomi Rands associadas com a doença da tinta do castanheiro 2004; UTAD. Vila Real. Doctoral tesis.

[16] Judelson H, Blanco F. The spores of Phytophthora: weapons of the plant destroyer. Nature Reviews Microbiology 2005; 3(1): 47-58. https://doi.org/10.1038/nrmicro1064

[17] Shearer B, Tippett Jarrah. Dieback: The Dynamics and Management of Phytophthora cinnamomi in the Jarrah (Eucalytus marginata) Forest of South-western Australia. Research Bulletin N. ${ }^{\circ} 3$, Department of Conservation and Land Management Como Western Australia 1989.

[18] Kimati H, Amorim L, Bergamim Filho A, Camargo L, Rezende J. Manual de Fitopatologia, Doenças das Plantas Cultivadas; Editora Agronômica Ceres Ltda, São Paulo 1997; Vol. 2.

[19] Hosseini S. Expression patterns of pathogenicity genes during Phytophthora pisi infection of pea roots. Independent Project in biology 2010; Master's thesis, 30 hp, EX0564.

[20] Hogenhout S, Van der Hoorn R, Terauchi R, Kamoun S. Emerging conceptsin effector biology of plant-associated organisms. Molecular Plant- Microbe Interactions 2009; 22: 115-122.

https://doi.org/10.1094/MPMI-22-2-0115

[21] Kamoun S. A catalogue of the effector secretome of plant pathogenic oomycetes. Annual Review of Phytopathology 2006; 44: 41-60. https://doi.org/10.1146/annurev.phyto.44.070505.143436

[22] Schornack S, Huitema E, Cano L, Bozkurt T, Oliva R, Van Damme M, Schwizer S, Raffaele S, Chaparro-Garcia A, Farrer R, Segretin M, Bos J, Haas B, Zody M, Nusbaum C, Win J, Thines M, Kamoun S. Ten things to knowabout oomycete effectors. Molecular Plant Pathology 2009; 10: 795-803.

https://doi.org/10.1111/j.1364-3703.2009.00593.x

[23] Hardham A. Pathogen profile: Phytothora cinnamomi. Molecular Plant Pathogy 2005; 6(6): 589-604. https://doi.org/10.1111/j.1364-3703.2005.00308.x

[24] Duclos J, Fauconnier A, Coelho A, Bollen A, Cravator A, Godfroid E. Identification of an Elicitin Gene Cluster in Phytophthora cinnamomi. Dna Sequence: The journal of DNA sequencing and mapping 1998; 9(4): 231-237. https://doi.org/10.3109/10425179809105210
[25] Kamoun S. Molecular Genetics of Pathogenic Oomycetes. Eukaryotic cell 2003; 10: 2(2): 191-199. https://doi.org/10.1128/EC.2.2.191-199.2003

[26] Montesano M, Brader G, Palva T. Pathogen derived elicitors: searching for receptors in plants. Molecular Plant Pathology 2003; 4(1) 73-79.

https://doi.org/10.1046/j.1364-3703.2003.00150.x

[27] Zentmyer G. Phytophthora cinnamomi and the diseases it causes. Monograph, American Phytopathological Society 1980 ; N. ${ }^{\circ} 10$, pp. 96 , pp. ref. 600 . ISBN: 0890540306.

[28] Moris B, Gow N. Mechanism of electrotaxis of zoospores of phytopathogenic fungi. Phytopathology 1993; 83: 877-882. https://doi.org/10.1094/Phyto-83-877

[29] Stamps D, Waterhouse G, Newhook F, Hall G. Revised tabular key to the species of Phytophthora. Mycological Paper 162. Commonwealth Mycological Institute, Kew, Surrey, UK 1990.

[30] Caetano P. Envolvimento de Phytophthora cinnamomi no declíneo de Quercus suber e Q. Rotundifolia: Estudo da influência de factores bióticos e abióticos na progressão da doença. Possibilidades de controlo químico do declíneo. Universidade do Algarve - Faculdade de Engenharia de Recursos Naturais 2007; Doctoral tesis.

[31] Cahill D, Bennett I, McComb J. Mechanisms of resistance to Phytophthora cinnamomi in clonal, micropropagated Eucalyptus marginata. Plant Pathol 1993; 42(6): 865-872. https://doi.org/10.1111/j.1365-3059.1993.tb02672.x

[32] Martins, M. Caracterização do gene gip de Phytophthora cinnamomi Rands associado à doença da Tinta do castanheiro e pesquisa de novos fitofármacos no controlo da doença. Instituto Politécnico de Bragança - Escola Superior Agrária 2010; Master tesis.

[33] Martins M. Caracterização do gene gip de Phytophthora cinnamomi Rands associado à doença da Tinta do castanheiro e pesquisa de novos fitofármacos no controlo da doença. Instituto Politécnico de Bragança - Escola Superior Agrária. Tese de Mestrado 2010.

[34] Götesson A, Marshall J, Hardham A. Characterization and evolutionary analysis of a large polygalacturonase gene family in the Oomycete plant pathogen Phytophthora cinnamomi. Molecular Plant-Microbe Interactions 2002; 15(9): 907-21. https://doi.org/10.1094/MPMI.2002.15.9.907

[35] Choupina A, Cravador A, Carvalho M, Vaz M, Belo $H$ Martins F, Martins I. Cloning, characterization and in vitro and in planta expression of a glucanase inhibitor protein (GIP) of Phytophthora cinnamomi. Mol Biol Rep 2014; 41: 2453-2462. https://doi.org/10.1007/s11033-014-3101-1

[36] Reitmann A, Berger D, van den Berg N. Putative pathogenicity genes of Phytophthora cinnamomi identified via RNA-Seq analysis of pre-infection structures. European Journal of Plant Pathology 2017; 147(1): 211-228. https://doi.org/10.1007/s10658-016-0993-8

[37] Armstrong M, Whisson S, Pritchard L, Bos J, Venter E, Avrova A, Rehmany A, Bohme U, Brooks K, Cherevach I, Hamlin N, White B, Fraser A, Lord A, Quail M, Churcher C, Hall N, Berriman M, Huang S, Kamoun S, Beynon J, Birch P. An ancestral oomycete locus contains late blight avirulence gene Avr3a, encoding a protein that is recognised in the host cytoplasm. Proceedings of the National Academy of Sciences of the United States of America (PNAS) 2005; 102: 7766-7771. https://doi.org/10.1073/pnas.0500113102

[38] Bos J, Armstrong M, Gilroy E. Phytophthora infestans effector AVR3a is essential for virulence and manipulates plant immunity by stabilizing host E3 ligase CMPG1. PNAS 2010; 107(21): 9909-9914.

https://doi.org/10.1073/pnas.0914408107 
[39] Rapoport T. Transport of proteins across the endoplasmic reticulum membrane. Science 1992; 258: 931-936. https://doi.org/10.1126/science.1332192

[40] Fry W, Goodwin S. Resurgence of the Irish potato famine fungus. Bioscience 1997; 47: 363-371. https://doi.org/10.2307/1313151
[41] Tinoco M, Dias B, Dall Astta R, Pamphile J, Aragão F. In vivo transspecific gene silencing in fungal cells by in plant expression of a double-stranded RNA. BMC Biology 2010; 8: 27.

https://doi.org/10.1186/1741-7007-8-27

Received on 20-05-2020

Accepted on 08-06-2020

Published on 27-06-2020

https://doi.org/10.29169/1927-5129.2020.16.03

(C) 2020 Branco and Choupina; Licensee SET Publisher.

This is an open access article licensed under the terms of the Creative Commons Attribution Non-Commercial License (http://creativecommons.org/licenses/by-nc/3.0/) which permits unrestricted, non-commercial use, distribution and reproduction in any medium, provided the work is properly cited. 